\title{
TRUE SHALLOT SEED PRODUCTION OF LOWLAND SHALLOT (BIRU LANCOR VARIETIES) UNDER THE APPLICATION OF SEAWEED EXTRACT AND N FERTILIZER
}

\author{
Istiqomah Nurul*, Postgraduate student \\ Faculty of Agriculture, University of Brawijaya \& Assessment Institute for Agricultural \\ Technology, Malang, Indonesia
}

\author{
Barunawati Nunun, Aini Nurul, Widaryanto Eko, Academic Staff \\ Department of Agronomy, Faculty of Agriculture, University of Brawijaya, Malang, Indonesia
}

*E-mail: nurulistiqomah194573@gmail.com

\begin{abstract}
The major problem on the improving shallot production is due to availability of quality tuber seeds requied by farmers in sufficient quantities. One effort that can be done in order to fulfill the seed production is to use TSS or True Seed of Shallot technology. For this reason, efforts are needed to improve nitrogen fertilizer efficiency following the application of seaweed extract along with different source of $\mathrm{N}$ fertilization. The research was carried out in the village of Sidomulyo, Batu, with an altitude of $923 \mathrm{~m}$ asl with planting material from seed growers in Probolinggo who have experienced on shalor seed production with seed a dormancy period of approximately 2 months. Seaweed Extract (RL) uses Citorin and ammonium nitrate using Calcium Ammonium Nitrate Fertilizer. For seeds to be planted, vernalization is carried out by inserting seeds into the refrigerator at $\pm 10^{\circ} \mathrm{C}$ for $3-4$ weeks. The study began in September 2018 and ends in January 2019. The study used a Factorial Randomized Group Design of 1 factor, namely the dose of Ammonium Nitrate with several concentrations of seaweed extract $(R L)$. The dose of Ammonium Nitrate consists of $0 \%(0 \mathrm{~kg}$ / ha), $50 \%$ (from the total $\mathrm{N}$ dose of $178 \mathrm{~kg} / \mathrm{ha}$ and $100 \%$ (as much as $178 \mathrm{~kg} / \mathrm{ha}$ ). The dosage of $\mathrm{N} 178 \mathrm{~kg}$ per hectare comes from the calculation of $\mathrm{N}$ content in doses recommendation is NPK $600 \mathrm{~kg} / \mathrm{ha}$ (NPK fertilizer contains $15 \% \mathrm{~N}), \mathrm{ZA} 200 \mathrm{~kg} / \mathrm{ha}(\mathrm{ZA}$

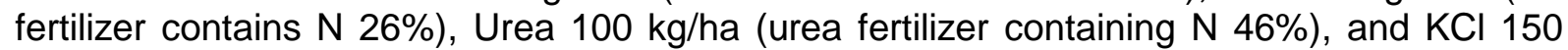
$\mathrm{kg} / \mathrm{ha}$ Seaweed extract with a concentration of 0 ppm, $120 \mathrm{ppm}, 240 \mathrm{ppm}, 360 \mathrm{ppm}$ and 480 ppm. Thus the treatment is as follows: (1) Control = $0 \% \mathrm{~N}$ and $0 \mathrm{ppm} \mathrm{RL}$; (2) N1 RL $120 \mathrm{ppm}$ (50\% dose N and 120 ppm RL); (3) N1 RL 240 ppm (50\% N and 240 ppm RL); (4) N1 RL 360 ppm (50\% dose N and 360 ppm RL); (5) N1 RL 480 ppm (50\% dose N and 480 ppm $\mathrm{RL}$ ); (6) N2 RL $120 \mathrm{ppm}(100 \% \mathrm{~N}$ and $120 \mathrm{ppm} \mathrm{RL}$ (7) N2 RL $240 \mathrm{ppm}$ (100\% N and 240 ppm RL (8) N2 RL 360 ppm (100\% N and 360 ppm RL); (9) N2 RL 480 ppm (100\% dose N and $480 \mathrm{ppm} \mathrm{RL}$ ). The variables observed were plant height, number of leaves, number of tillers and number of tubers per plant, $50 \%$ bloom time, number and height of stem, root dry weight, canopy dry weight, number of flowers per stem, number of kernels per stem, percentage of flowers being kernels, weight of 1 seed, seed weight per $1000 \mathrm{~m}^{2}$, mini tuber production. Data from the observations were analyzed using ANOVA and if there was a significant effect followed by LSD at the level of $5 \%$ to see the differences between treatments.
\end{abstract}

\section{KEY WORDS}

Amonium nitrate, flowering, vernalization, shallot seed, seaweed exctract.

The production of new national shallot bulb seeds can meet $15-16 \%$ of the total demand (Director General of Horticulture, 2010). Data for red onion production in Indonesia in 2013 was recorded at 1.010 .733 tons, with an import volume of $124.544,25$ tons resulting in an average requirement of $2.07 \mathrm{~kg} \mathrm{person}^{-1}$ year $^{-1}$. In 2017, the need for shallots tuber is projected to increase to 1.244 .278 ton, which could divided into several segments: (1) consumption at 994,378 ton, (2) 104,900 ton for seeds, (3) 40.000 ton for industry and (5) 
105.000 ton for fulfilling exports. When the average productivity of shallots is projected to reach 10.22 tons $\mathrm{ha}^{-1}$, then in 2017 there will be around 121.749 ha of harvested area. Referring to the 2012 harvest area, which was equal to 99.519 ha, the fulfillment of the demand for shallots in 2017 requires an additional expansion of the harvested area of around 22.230 ha. An additional area of 22.230 ha requires additional tuber seeds $\left(1.5\right.$ ton ha $\left.{ }^{-1}\right)$ of 33.345 tons so that the total need for 2017 tuber seeds should be in the range of 138.245 ton. However, the quality tuber seeds needed by farmers are not sufficient in quantity and those availability at the market, due to achieving rapid grow of the shallot production it is required to optimize seed tuber production (Hilman et al., 2014; Rosliani et al., 2016).

The availability of tuber seeds is predicted to only be able to meet $75.87 \%$. If the tuber demand are replaced with TSS (True Shallot Seed) $(5 \mathrm{~kg} / \mathrm{ha})$ then the requrement for this in 2017 is 111 ton (processed BPS data, 2014). Red shallot (Allium ascalonicum L.) is one of the important vegetable species which is a national superior commodity (Rosliani et al., 2013; Fritsch and Fiesen, 2002; Sopha et al., 2014). As a result, farmers meet the needs of seeds by producing their own seeds. The use of seeds themselves which is carried out continuously can cause a decrease in productivity and is prone to root tuber diseases such as Fusarium and Colletotrichum (Sumarni and Rosliani, 2010; Rosliani, 2013). Some other problems faced in the production and use of tuber seeds are more expensive especially when the tuber seed stock is limited, requires greater storage space, higher transportation costs due to volume, and tuber seed production ratio is lower than seed production ratio. The average tuber production ratio is $1: 10$ while the seed production ratio can reach 1:200. The onion seed dormancy period is 2-3 months and if stored for a longer period (> 3 months) there will be a decrease in quality. The advantage of using tuber seeds is that they do not require pollination and complicated technology to replant because the bulb size is quite large (Sumarni and Rosliani, 2010; Rosliani, 2013).

In order to meet the demand of shallot seeds, use the TSS method or botanical seeds. TSS seeds that are an alternative to tuber seeds have several advantages, among others, are healthier seeds, have a higher seed production ratio than tuber production and have a longer dormancy period of more than 2 years (Rosliani et al., 2016). TSS production still faces several challenges, among others, the percentage of flowering and seed formation is still low. Therefore the production of red onion TSS is a very interesting study material because TSS can be an alternative to meet the demand of seeds at the farmer level, thus opening opportunities in efforts to increase national shallot production. Khokar (2014) stated that flowering stimulation in shallots in TSS seed production is influenced by many factors starting from the vernalization process, bulb size, environmental conditions after planting and varieties.. Biostimulants are known as ingredients and/or microorganisms that can increase absorption of nutrient absorption by rooting plants, especially nitrogen. At present the use of biostimulant seaweed extract on shallots is still limited. Farmers generally use $\mathrm{GA}_{3}$. Seaweed extract has several advantages compared to $\mathrm{GA}_{3}$ because in addition to containing gibberelin there is also a cytokinin which, among others, functions to accelerate flowering and increase uniformity of flowering time in addition to its function in increasing fertilizer efficiency. Research on the nutrient requirements of Nitrogen, especially Ammonium Nitrate $\left(\mathrm{NH}_{4} \mathrm{NO}_{3}\right)$ in TSS production is still not widely used. The aim of the study was to study the potential of ammonium nitrate and seaweed nitrogen in shallot seed production.

The Ministry of Agriculture has issued a package of TSS production technology consisting of components of site selection technology, vernalization, fertilization, and the application of $\mathrm{GA}_{3}$ and BAP biostimulants (Rosliani et al., 2016) The solution to increase the percentage of seed formation is by using the vernalization technique. Regarding the vernalization technology component, research that looks at the mechanism of shallot seed production through vernalization techniques is still very limited (Wu et al., 2016). The use of $10^{\circ} \mathrm{C}$ vernalization temperatures in the highlands in Bima varieties has provided information that TSS production can reach 8.12 grams per 12 plants (Hilman et al., 2014). Besides that the fertilizer component is an important strategy in increasing shallot production. However, irrational use of $\mathrm{N}$ and carried out continuously will cause an imbalance of nutrients in the soil and degradation of soil fertility which has an impact on decreasing yields. Biostimulant 
applications such as the application of Growth Regulating Substances (ZPT) and growth stimulants such as Benzyl Amino Purine (BAP) and Giberellic Acid $\left(\mathrm{GA}_{3}\right)$ are also important components that influence TSS production. It's just that a number of previous studies have shown that the effect of the application of $\mathrm{GA}_{3}$ growth regulators is still varied or unstable, increasing the productivity of shallots. The results of the study (Rosliani et al., 2016) showed no interaction between varieties (Pancasona and Mentes) and the way $\mathrm{GA}_{3}$ was applied to plant growth, flowering and TSS yield of shallots.

In view of this, the improvement of TSS seed production technology components is a very interesting study material, among others studies on tuber vernalization aspects (storage of tubers at low temperatures), application of $\mathrm{N}$ sources in the form of ammonium, nitrate and ammonium nitrate for $\mathrm{N}$ availability evaluation. the use of biostimulant using alternative ingredients such as seaweed extract (Euchema spinossum) so that it can be seen the effectiveness in increasing productivity of the results of onion TSS. The objective of this study was to evaluate the response of shallot varieties to the type and dose of biostimulant and the dosage and source of $\mathrm{N}$ fertilizer as a component of TSS production technology in increasing the speed of flowering initiation and yield of TSS seed varieties of specific location, namely Blue Lancor variety.

\section{METHODS OF RESEARCH}

The study was conducted in Sidomulyo Village, Batu City with an altitude of $923 \mathrm{~m}$ above sea level. The study was performed in a plastic house (greenhouse) starting at September 2018 to January 2019. This location was approximately 30 miles from the central city of Malang, with geograhic position at $7^{\circ} 51^{\prime} 12.29^{\prime \prime} \mathrm{S}$ and $112^{\circ} 31^{\prime} 25.62^{\prime \prime} \mathrm{E}$.

The research will be carried out using onion seeds which previously have been vernalized at $10^{\circ} \mathrm{C}$ for $2-4$ weeks. Plastic houses (greenhouses) are made with an area of approximately $150-300 \mathrm{~m}^{2}$. Silver black (SB) plastic mulch is used to cover beds, biostimulants in the form of seaweed extract (using Citorin), Calcium Ammonium Nitrate fertilizer as a source of Ammonium Nitrate, SP-36 as a source of P and KCl for K. N,P, and K fertilizers are given in 2 periods, starting from the planting period to optimal vegetative growth and the period of flowering formation to harvest. Fertilizer is being applied according to the recommendation level, which were equal to $600 \mathrm{~kg} \mathrm{ha}^{-1} \mathrm{NPK}, 200 \mathrm{~kg} \mathrm{ha}^{-1}$ Urea and $100 \mathrm{~kg}$ $\mathrm{ha}^{-1} \mathrm{ZA}$ (Ministry of Agriculture, 2014). The second period, fertilizer was given in the form of Ammonium nitrate, SP-36 and KCl equivalent to a dose of $100 \mathrm{~kg} \mathrm{ha}^{-1} \mathrm{NPK}$ and boron as much as $3 \mathrm{~kg} \mathrm{ha}^{-1}$. Pesticides was used for controlling plant pest organisms, manure or petroganics were applied for fulfilling basic fertilizers. Boron fertilizer as much as $3 \mathrm{~kg} \mathrm{ha}^{-1}$ and additional SP-36, KCl, and Ammonium nitrate fertilizer as much as $100 \mathrm{~kg} \mathrm{ha}^{-1}$ to support flower growth. The supporting equipment for research were used including ruler, raffia, measuring cup, micro pipette, analytic scales, minimum-maximum thermometer, hand sprayer and oven, pollinator insects that help pollinate and tray processes for harvesting and bamboo stick to support flower stalks (belalo) during flowering to seed harvest.

The study was used Randomized Complete Block Design (RCBD), whereas the application of Nitrogen Ammonium Nitrate under the combination of Seaweed Extract $(R L)$ and this were repeated 3 times. The list of treatments is given in Table 1.

Table 1 - The detail information of each treatments

\begin{tabular}{|c|c|c|}
\hline Code & Treatments combination & Remarks \\
\hline$(\mathrm{A} 0)$ & Control & $0 \% \mathrm{~N}$ dosage (equal to $\left.=0 \mathrm{~kg} \mathrm{~N} \mathrm{ha}^{-1}\right)+0 \mathrm{ppm} \mathrm{RL}$ \\
\hline$(\mathrm{A} 1)$ & N1 RL 120 ppm & $50 \% \mathrm{~N}$ dosage (equal to $=89 \mathrm{~kg} \mathrm{~N} \mathrm{ha}^{-1}$ ) $+120 \mathrm{ppm} \mathrm{RL}$ \\
\hline (A2) & N1 RL 240 ppm & $50 \% \mathrm{~N}$ dosage (equal to $\left.=89 \mathrm{~kg} \mathrm{~N} \mathrm{ha}^{-1}\right)+240 \mathrm{ppm} \mathrm{RL}$ \\
\hline (A3) & N1 RL 360 ppm & $50 \% \mathrm{~N}$ dosage (equal to $=89 \mathrm{~kg} \mathrm{~N} \mathrm{ha}^{-1}$ ) $+360 \mathrm{ppm} \mathrm{RL}$ \\
\hline$(\mathrm{A} 4)$ & N1 RL 480 ppm & $50 \% \mathrm{~N}$ dosage (equal to $=178 \mathrm{~kg} \mathrm{~N} \mathrm{ha}^{-1}$ ) $+480 \mathrm{ppm} \mathrm{RL}$ \\
\hline (A5) & N2 RL 120 ppm & $100 \% \mathrm{~N}$ dosage (equal to $=178 \mathrm{~kg} \mathrm{~N} \mathrm{ha}^{-1}$ ) $+120 \mathrm{ppm} \mathrm{RL}$ \\
\hline (A6) & N2 RL 240 ppm & $100 \% \mathrm{~N}$ dosage (equal to $\left.=178 \mathrm{~kg} \mathrm{~N} \mathrm{ha}^{-1}\right)+240 \mathrm{ppm} \mathrm{RL}$ \\
\hline (A7) & N2 RL 360 ppm & $100 \%$ dosis $\mathrm{N}$ (equal to $\left.=178 \mathrm{~kg} \mathrm{~N} \mathrm{ha}^{-1}\right)+360 \mathrm{ppm} \mathrm{RL}$ \\
\hline (A8) & N2 RL 480 ppm & $100 \%$ dosis $\mathrm{N}$ (equal to $=178 \mathrm{~kg} \mathrm{~N} \mathrm{ha}^{-1}$ ) $+480 \mathrm{ppm} \mathrm{RL}$ \\
\hline
\end{tabular}


The use of UV plastic shade on plastic housing or greenhouse was carried out during the research in an effort to minimize crop failure. The structure UV plastic shade uses a bamboo frame and the shape of a semi-circular roof with a circle peak height of approximately 4 meters and a height of the right and left side of the shade of 2 meters. Around the house the plastic is installed with paranet to control pest and disease outbreak.

The study used experimental plots in the form of beds with a size of approximately $2 \mathrm{~m}$ $x 1 \mathrm{~m}$. The distance between beds in the replication is $30 \mathrm{~cm}$ and the distance between beds between replications is $50 \mathrm{~cm}$. The land is processed perfectly by hoeing and leveling the soil surface. After that, manure is given at a dose of 20 tons per hectare or approximately $0.5 \mathrm{~kg}$ per bed.

Silver black plastic mulch is installed along the beds by installing wooden pegs around the beds. Installation of mulch is done a week before planting. Mulch used is with a width of $120 \mathrm{~cm}$ plastic size $\mathrm{x}$ length of the bed.

Planting holes are made by heating iron rings by burning wood charcoal on top. This tool is specifically designed for making planting holes above plastic mulch. Making a planting hole by observing the spacing of $15 \times 20 \mathrm{~cm}$, which is $15 \mathrm{~cm}$ between lines and $20 \mathrm{~cm}$ in distance so that there are approximately $5 \times 10$ plants $=50$ plants per bed.

Planting is done on seeds that have been vernalized for $2-4$ weeks at $10^{\circ} \mathrm{C}$. Before being planted, first the seed bulbs are sprayed with a $2 \mathrm{ml}$ per liter biostimulant solution according to the concentration of the treatment then dried. After that the bulb seeds are cut $1 / 3$ the end for the bulbs ready to be planted. Planting by making a planting hole $1-2 \mathrm{~cm}$ deep and the tubers covered with a mixture of soil and manure.

Watering is done twice a day in the morning before sunrise and evening or according to land conditions and weather in the field. Watering uses a stringy so that it does not damage the tuber seeds and the seeds are not thrown from the planting hole.

In the rainy season, it is estimated that more diseases attack the onion plants compared to pests. The main disease is fusarium which can cause plants to not grow normally and must be eradicated so as not to spread to other plants around it. Pest and disease control is controlled by the application of pesticides as recommended. To prevent severe attacks, monitoring is carried out every day morning and evening together with watering activities.

Fertilization with a distance of $5 \mathrm{~cm}$ from the base of the plant. After that watering is done. $\mathrm{P}$ and $\mathrm{K}$ fertilizers are in accordance with the recommended dosage which is equivalent to $600 \mathrm{~kg} \mathrm{NPK} \mathrm{ha}^{-1}, 200 \mathrm{~kg} \mathrm{ha}^{-1}$ Urea, and $100 \mathrm{~kg} \mathrm{ha}^{-1} \mathrm{KCl}$. Fertilization is done twice, namely when the plants are 15 and 30 days after planting. When the plants are out, SP-36, $\mathrm{KCl}$, and Ammonium nitrate fertilizers are added at a dose of $100 \mathrm{~kg} / \mathrm{ha}$ for plant maintenance in supplying the nutritional needs of plants starting from flowering to harvesting seeds. The time of application of additional fertilizers according to the conditions of the plants in the field, carried out up to 5 times at 10-day intervals and added boron with a dose of $3 \mathrm{~kg}$ $\mathrm{ha}^{-1}$ to help improve the ability of plants in seed formation.

Mounting the support to support the erection of the umbel or the main flower stem that appears. In 1 clump of plants usually grow 2-3 tubers. If no attachment is installed, the umbel will break or collapse and die. Installation is done when the plants are 35-40 days after planting.

Biostimulant is applied when the plant is approaching the tuber formation phase and the flower has not yet come out. This phase is estimated when the plants are 25-45 days after planting. Biostimulant application 3 times at 7 days interval. The spray volume is 300 liters per hectare so that the volume of spray per plant is 1.2 milliliters.

Insect pollinator intervention to help pollinate the shallot seed production. Insect pollinators use the intervention of green flies (Calliphora vomitoria)

Harvesting of seeds is done when plants start 88 days after planting and are harvested three times until the plants are 99 days after planting with harvest intervals 3-4 days depending on plant conditions and weather on the land. Mini bulbs are tubers produced by shallots after the seeds are harvested. 
Measurement were made in the vegetative phase, generative planting. Variables and time of observation are as follows:

Observations were made by calculating the number of flower stalks that appeared with flowers that had been fully bloomed in all plants in each treatment plot. Observations were made at 63 HST.

It is done by calculating the shallot seed weight produced. Observations were made by weighing the seeds produced in all kernels in each treatment plot. Observations are made at harvest time, after finishing processing the seeds. The stages are as follows: the harvested flowers are dried, separated from the stover, and manually extracted seeds in the kernel, then weighed using a scale.

Observations were carried out by weighing the harvested tubers which at the same time as the shallot seed harvest, collecting from the tubers weight produced per plot of the treatments.

Root dry weight and above ground biomass dry weight were carried out by destructive sampling and weighing the harvested their fresh weight before placing into the oven overnight at $60^{\circ} \mathrm{C}$ to derive dry weight for the next following days measurtement.

The data obtained were analyzed by ANOVA and if there was a significant effect followed by Fisher LSD analysis (5\%) to find out the differences between treatments.

\section{RESULTS OF STUDY}

The results the analysis of variance showed that the treatment had a significant effect on time of flower with $75 \%$ of flower in full blooming period and stalk height per plant $(\mathrm{P}<0.05)$ but not significantly effected on the number of stalk observed at 63 DAP (days after planted) (Table 2).

Table 2 - The time flower appears with $75 \%$ of flowers in full blooming period, the number and height of flower stalks 63 HST due to the application of seaweed extract and ammonium nitrate fertilizer

\begin{tabular}{llll}
\hline Treatment & $\begin{array}{l}\text { Time of flower appear } \\
\text { with 75\% of flower in full } \\
\text { blooming period (DAP) }\end{array}$ & $\begin{array}{l}\text { Height of stalk }(\mathrm{cm}) \text { 63 } \\
\text { HST }\end{array}$ & $\begin{array}{l}\text { Number of stalk 63 } \\
\text { DAP (stalk per seed } \\
\text { bed) }\end{array}$ \\
\hline Control & $50,67 \mathrm{ab}$ & $52,17 \mathrm{~b}$ & 10,67 \\
N1 RL 120 ppm & $50,33 \mathrm{a}$ & $54,19 \mathrm{ab}$ & 12,33 \\
N1 RL 240 ppm & $50,67 \mathrm{ab}$ & $49,37 \mathrm{a}$ & 10,67 \\
N1 RL 360 ppm & $52,67 \mathrm{abc}$ & $56,50 \mathrm{c}$ & 13,67 \\
N1 RL 480 ppm & $53,00 \mathrm{abc}$ & $54,17 \mathrm{bc}$ & 12,00 \\
N2 RL 120 ppm & $54,00 \mathrm{bc}$ & $51,35 \mathrm{ab}$ & 12,67 \\
N2 RL 240 ppm & $54,33 \mathrm{c}$ & $53,40 \mathrm{bc}$ & 14,33 \\
N2 RL 360 ppm & $55,33 \mathrm{c}$ & $52,94 \mathrm{~b}$ & 15,00 \\
N2 RL 480 ppm & $54,67 \mathrm{c}$ & $49,43 \mathrm{a}$ & 12,33 \\
\hline CV $(\%)$ & 3,80 & 9,1 & 16,60 \\
\hline LSD & 3,484 & 3,448 & 3,632 \\
\hline Probability & $\left(^{*}\right)$ & $\left(^{*}\right)$ & $(\mathrm{ns})$ \\
\hline
\end{tabular}

Note: The numbers accompanied by the same letters in each column show no significant differences at LSD (5\%); N1 = $96 \mathrm{~kg} \mathrm{ha}^{-1} \mathrm{~N}-\mathrm{NH}_{4} \cdot \mathrm{NO}_{3} ; \mathrm{N} 2=178 \mathrm{~kg} \mathrm{ha}{ }^{-1} \mathrm{~N}-\mathrm{NH}_{4} \cdot \mathrm{NO}_{3}, \mathrm{RL}=$ seaweed extract, $\left(^{*}\right)=$ significant, ns: not significant at $P(<0.05)$.

The growing time required for flower being appeared with a $75 \%$ of flower in full blooming period at control treatment was 50.67 DAP, which was not significantly different to those $\mathrm{N} 1$ treatment at all $\mathrm{RL}$ concentrations $(120,240,360$ and $480 \mathrm{ppm})$, except for $\mathrm{N} 2$ treatment. This meant that the application of higher dose of $178 \mathrm{~kg} \mathrm{ha}{ }^{-1} \mathrm{~N}-\mathrm{NH}_{4} \cdot \mathrm{NO}_{3}(\mathrm{~N} 2)$ exaggerating time for shallot for producing flower slower than low dose application In addition, the treatment of control was not significantly different to all $\mathrm{N} 1$ treatment (lower dose of $\mathrm{N}$ fertilizer).

In term of flower stalk height, the greatest was obtained from the treatment of $N 1 \mathrm{RL}$ $360 \mathrm{ppm}$, which is not significantly different to N1 RL $480 \mathrm{ppm}$ and N2 RL $240 \mathrm{ppm}$ treatments. In comparison to control, generally the height of the stalk at the $\mathrm{N} 1$ dose 
treatment increased with the addition of $\mathrm{RL}$ concentrations except at $480 \mathrm{ppm}$ but on the contrary, at the higher $\mathrm{N} 2$ dose the stalk height decreased with increasing RL concentration so that N2 480 ppm treatment produced the lowest stalk height. The treatment of N1 RL 240 ppm producing the lowest height of stalk which was not significantly diiferent to N1 RL 120 ppm, N2 RL 120 ppm and N2 RL 480 ppm.

The results of the variance analysis showed that the treatment had no effect on the variable number of flowers per flower and the percentage of flowers into capsules $(P<0.05)$ but it was significantly affected the variable number of capsules per stalk (Table 3).

Table 3 - Amount of flower, number of capsules and percentage of flower amount to be capsules due to application of seaweed extract and ammonium nitrate

\begin{tabular}{llll}
\hline Treatment & $\begin{array}{c}\text { Average amount of } \\
\text { flowers (flower/stalk) }\end{array}$ & $\begin{array}{l}\text { Number of capsules } \\
\text { (capsule/stalk) }\end{array}$ & $\begin{array}{c}\text { Precentage of flower } \\
\text { amount to be capsules } \\
(\%)\end{array}$ \\
\hline Kontrol & 59,67 & $6,60 \mathrm{a}$ & 15,42 \\
N1 RL 120 ppm & 57,00 & $9,87 \mathrm{a}$ & 20,11 \\
N1 RL 240 ppm & 65,58 & $12,00 \mathrm{bc}$ & 27,05 \\
N1 RL 360 ppm & 75,00 & $10,29 \mathrm{ab}$ & 17,49 \\
N1 RL 480 ppm & 73,58 & $12,75 \mathrm{bc}$ & 23,56 \\
N2 RL 120 ppm & 63,67 & $13,76 \mathrm{c}$ & 27,51 \\
N2 RL 240 ppm & 73,25 & $15,57 \mathrm{~cd}$ & 29,14 \\
N2 RL 360 ppm & 89,67 & $16,69 \mathrm{~d}$ & 25,18 \\
N2 RL 480 ppm & 67,83 & $15,57 \mathrm{~cd}$ & 33,76 \\
\hline CV $(\%)$ & 22,6 & 15,52 & 27,4 \\
\hline LSD & 27,17 & 4,317 & 11,57 \\
\hline Probalility & $\mathrm{ns}$ & $\left.{ }^{*}\right)$ & $\mathrm{ns}$ \\
\hline
\end{tabular}

Note: The numbers accompanied by the same letters in each column show no significant differences at LSD (5\%); $\mathrm{N1}=96 \mathrm{~kg} \mathrm{ha}{ }^{-1} \mathrm{~N}-\mathrm{NH}_{4} \cdot \mathrm{NO}_{3} ; \mathrm{N} 2=178 \mathrm{~kg} \mathrm{ha}^{-1} \mathrm{~N}-\mathrm{NH}_{4} \cdot \mathrm{NO}_{3}, \mathrm{RL}=$ seaweed extract, ( $\left(^{*}\right)$ = significant, ns: not significant at $P(<0.05)$.

The highest number of capsules per stalk was found in the treatment of N2 RL 360 ppm as many as 16.69 capsules per stalks in which it was significantly different to controls which only able to produce capsules as much as 6.60 capsules per stalks. However there was no significantly different on the number of capsules per stalk between N2 RL 360 ppm and lower application of RL (N2 RL $240 \mathrm{ppm}$ ) or even higher (N2 RL $480 \mathrm{ppm}$ ). The average number of capsules per stalk at lower $\mathrm{N}$ fertilizer (N1) under various concentrations of $\mathrm{RL}$ was contributed to the increasing of those value by $70.15 \%$ compared to controls. In addition, the application of higher dose of $\mathrm{N}$ fertilizer (N2) at all concentrations of $\mathrm{RL}(120,240,360$ and 480 ) was resulting in the raising of an average number of capsules per stalk by $133 \%$. The number of capsule per stalk in the treatment of $\mathrm{N} 2$ at various concentrations of RL (120, 240,360 , and $480 \mathrm{ppm}$ ) was higher than that those treatment of $\mathrm{N} 1$.

Table 4 - Weight per 1 seed, seed weight per $1000 \mathrm{~m}^{2}$, tuber weight per plot size of $2 \mathrm{~m}^{2}$ due to application of seaweed extract and ammonium nitrate

\begin{tabular}{|c|c|c|c|}
\hline \multirow{2}{*}{ Treatment } & \multicolumn{2}{|c|}{ Seed weight } & \multirow{2}{*}{$\begin{array}{l}\text { Tuber weight per plot ( } \mathrm{g} \\
\text { per } 2 \mathrm{~m}^{2} \text { ) }\end{array}$} \\
\hline & (mg per seed) & (g per $\left.1000 m^{2}\right)$ & \\
\hline control & 1,79 & $578,67 \mathrm{a}$ & $32.00 \mathrm{a}$ \\
\hline N1 RL 120 ppm & 1,28 & $663,33 \mathrm{~b}$ & $50.33 \mathrm{bc}$ \\
\hline N1 RL 240 ppm & 1,33 & $680,67 \mathrm{bc}$ & $60.00 \mathrm{e}$ \\
\hline N1 RL $360 \mathrm{ppm}$ & 1,65 & $921,67 d$ & $61.00 \mathrm{f}$ \\
\hline N1 RL $480 \mathrm{ppm}$ & 1,69 & $729,67 \mathrm{c}$ & $57.67 \mathrm{e}$ \\
\hline N2 RL $120 \mathrm{ppm}$ & 1,78 & $903,17 d$ & $45.33 \mathrm{~b}$ \\
\hline N2 RL 240 ppm & 1,17 & $687,67 \mathrm{bc}$ & $56.33 \mathrm{de}$ \\
\hline N2 RL 360 ppm & 1,15 & $983,33 \mathrm{e}$ & $53.33 \mathrm{~cd}$ \\
\hline N2 RL 480 ppm & 1,27 & $895,67 \mathrm{~d}$ & $57.33 \mathrm{de}$ \\
\hline CV (\%) & 23,9 & 28,4 & 15,73 \\
\hline LSD & 0,6026 & 507,1 & 4,77 \\
\hline Probability & ns & $\left({ }^{*}\right)$ & $\left(^{*}\right)$ \\
\hline
\end{tabular}


The results of the variance analysis showed that the treatment did not significantly influence the weight per 1 seed but it was significantly affected the seed weight in each 1,000 $\mathrm{m}^{2}$ and tuber weight (Table 4).

In general, seed weight in all treatment were significantly higher than those of control $(P<0.05)$. The lowest seed weight per $1,000 \mathrm{~m}^{2}$ is in the control (578.67 grams), whilst the highest was found under the treatment of N2 RL 360 ppm (983.33 grams). Among the treatments, N2 RL 360 ppm produced highest seed weight $\left(983,33 \mathrm{~g}\right.$ per $\left.1000 \mathrm{~m}^{2}\right)$, in which those value are almost twice than the control, and it was significantly different to other treatment, before it was drop to $895,67 \mathrm{~g}$ per $1000 \mathrm{~m}^{2}$ at the treatment of $\mathrm{N} 2 \mathrm{RL} 480 \mathrm{ppm}$. The average seed weight in treatment $\mathrm{N} 1$ (at all concentrations of $\mathrm{RL} 120,240,360,480$ ppm) was $748.84 \mathrm{~g}$ in which it was lower than those average seed weight of N2 (at all concentrations of RL 120, 240, 360, 480 ppm), reached $867.46 \mathrm{~g}$. This means that there was an increasing on seed weight by $29.41 \%$ and $49.90 \%$ compare to control treatment, respectively.

In contrast, in term of tuber weight, the highest was detected under N1 RL $240 \mathrm{ppm}$ treatments $\left(60 \mathrm{~g}\right.$ per $\left.2 \mathrm{~m}^{2}\right)$ which was not significantly different to the treatment of $\mathrm{N} 1 \mathrm{RL} 480$ ppm, N2 RL 240 ppm and N2 RL 480 ppm, producing tuber weight at 57.67, 56.33 and 57.33 g per $2 \mathrm{~m}^{2}$, respectively.

The average tuber weight produced in the $\mathrm{N} 1$ treatment at all $\mathrm{RL}$ concentrations was $58.00 \mathrm{~g}$ while for the $\mathrm{N} 2$ treatment in all concentrations produced an average tuber weight at of $53.08 \mathrm{~g}$ per $2 \mathrm{~m}^{2}$. This acccounrted for the increasing of tuber weight at $81.25 \%$ for low fertilizer dose (N1) and $65.88 \%$ for high dose N fertilizer (N2) treatment.

The results of analysis of variance showed that the treatment significantly affected the root dry weight and aboveground biomass dry weight $P(<0.05)$ (Table 5$)$. The lowest root dry weight were found in control $(0.09 \mathrm{~g} / \mathrm{plant})$ and the highest was treated with $\mathrm{N} 1 \mathrm{RL} 480 \mathrm{ppm}$ (0.28 g/plant) which was not significantly different to N1 RL $120 \mathrm{ppm}$. The higher dose of fertilizer (N2) did not influence root dry weight since there was no significantly different to all $\mathrm{RL}$ concentrations (120, 240, 360 and $480 \mathrm{ppm})$.

Table 5 - Root dry weight and aboveground biomass dry weight due to application of seaweed extract and ammonium nitrate fertilizer

\begin{tabular}{lll}
\hline Treatment & Root dry weight (g/plant) & Aboveground biomass dry weight (g/plant) \\
\hline Control & $0,09 \mathrm{a}$ & $0,81 \mathrm{a}$ \\
N1 RL 120 ppm & $0,24 \mathrm{~cd}$ & $1,67 \mathrm{bc}$ \\
N1 RL 240 ppm & $0,16 \mathrm{ac}$ & $1,15 \mathrm{ab}$ \\
N1 RL 360 ppm & $0,14 \mathrm{ab}$ & $1,33 \mathrm{abc}$ \\
N1 RL 480 ppm & $0,28 \mathrm{~d}$ & $1,87 \mathrm{c}$ \\
N2 RL 120 ppm & $0,15 \mathrm{ab}$ & $1,35 \mathrm{abc}$ \\
N2 RL 240 ppm & $0,20 \mathrm{bc}$ & $1,35 \mathrm{abc}$ \\
N2 RL 360 ppm & $0,20 \mathrm{bc}$ & $1,68 \mathrm{bc}$ \\
N2 RL 480 ppm & $0,19 \mathrm{bc}$ & $1,70 \mathrm{bc}$ \\
\hline CV $(\%)$ & 22,10 & 23,90 \\
\hline LSD & 0,07010 & 0,5931 \\
\hline Probability & $\left(^{*}\right)$ & $\left(^{*}\right)$ \\
\hline
\end{tabular}

Note: The numbers accompanied by the same letters in each column show no significant differences at LSD (5\%); $\mathrm{N1}=96 \mathrm{~kg} \mathrm{ha}{ }^{-1} \mathrm{~N}-\mathrm{NH}_{4} \cdot \mathrm{NO}_{3} ; \mathrm{N} 2=178 \mathrm{~kg} \mathrm{ha}^{-1} \mathrm{~N}-\mathrm{NH}_{4} \cdot \mathrm{NO}_{3}, \mathrm{RL}=$ seaweed extract, $\left(^{*}\right)$ = significant, ns: not significant at $P(<0.05)$.

Generally, the additional of $\mathrm{N}$ fertilizer increase root dry weight and above ground biomass at the range of 20 to $100 \%$ in all treatments compare to control, eventhough there were no clear evidence that under higher concentration of $\mathrm{N}$ fertilizer (N2) was given better result. The lowest aboveground biomaas weight was detected in the control which is not significantly different to N1 RL 240 ppm, N1 RL 360 ppm, N2 RL 120 ppm and N2 RL 240 $\mathrm{ppm}$. The treatment of low $\mathrm{N}$ fertilizer (N1) and high $\mathrm{N}$ fertilizer (N2) at all concentrations of $\mathrm{RL}$ caused an average increasing in dry weight by $85.80 \%$ and $87 \%$ respectively. The dry weight of the aboveground biomass has the similar pattern to root dry weight affected by those treatment. 


\section{DISCUSSION OF RESULTS}

Related to the time the flower stalk to be appeared, Rosliani et al. (2016) have conducted in-depth research related to the flowering phase of shallots for seed production. The results of the study showed that flowering time with $75 \%$ of flower in full blooming occurred at 62-66 DAP while in this study the flowering time were found at $50.33-54.67$ DAP, which meant the period was coming earlier. Harvesting time in Rosliani et al. (2016) up to 107 days, whlist on this experiment were reduced to 99 days. This is due to the effect of treatment which adding seaweed extract, therefore the period of flowering was changes. In addition there was also a differences on the locataion, which from the climatic, geographic and also evelation perspective was different. The difference of shallot flowering to be appeared with $75 \%$ of flower in full blooming period between low dose fertilizer application (N1) and high dose fertilizer application (N2) was due to a shortage of $\mathrm{N}$ in the plant, therefore under N1 or even in control becomes flowering faster. The results of this study in line with Gebretsadik and Dechassa (2018) explain that nitrates or nitrogen at lower doses encourage flowering while nitrates or nitrogen at high doses delay flowering. Likewise with the results of the study of Kant et al. (2011), Castro Marin et al. (2011), and Yuan et al (2016) that nitrogen lower than the optimal dose will encourage flowering while nitrogen at higher doses will extend the period vegetative period of plants (Gebretsadikdan Dechassa, 2018). There are differences in the response of plants to flowering due to nitrogen treatment because nitrogen is an important macronutrient for plants, and regulates many aspects of plant growth and development. Nitrogen has been reported to regulate flowering (Lin and Tsay, 2017). It was also explained that only nitrogen was found to have an effect other than the plant height, it also affected the number of plant days to flowering and seed yield (Abdissa et al., 2011). However, the results of this study are different from some of the studies conducted by Castro Marín et al. (2011), Yuan et al., 2016) which explained that plants grown at low $\mathrm{N}$ levels will experience slower flowering. In term of number of capsule per stalk which is the lowest to be found in control is also being affected by the low $\mathrm{N}$ suppliey to this treatment. The increasing number of capsule per talk were between 70 to $133 \%$ under the treatment of low application of $\mathrm{N}$ fertilizer (N1) and high dose $\mathrm{N}$ fertilizr (N2), respectively. This research is in line with (Gustfson, 2010) that the fruit and seed resistance is higher in plants with higher nitrogen doses because nitrogen can increase phospor and potassium uptake coupled with research conducted by Du Jurdin (2015) that the addition of biostimulants increases the effectiveness absorption of nutrients by roots to N, P and $\mathrm{K}$. In this research research, ammonium nitrate was used, where nitrate itself is a common form of nitrogen and influences plant regulation in various aspects of plant development. Nitrates provide nutrients and are reported to affect the growth of seeds, roots and leaves, root architecture, flowering time, branch formation, and plant aging, and affect crop yields (Crawford and Forde, 2002; Guiboileau et al., 2012; Stitt, 1999; Vidal et al., 2014). Meanwhile, flowering is the transition between the vegetative phase and plant reproductive growth so that this flowering period is a critical period in the role of future generations of plant sustainability and is very influential on fertility or the ability to support plant growth (Srikanth and Schmid, 2011).

In this study, flowering and seeding occurred in the rainy season at the end of November 2018. According to Rosliani et al. (2016) that during the rainy season pollinating insect activity decrease when compared to its activities in the dry season, especially in Apis serana and Vespidae insects. The emergence of $75 \%$ of flowers in full blooming period of all treatments were 52.85 days which is between December (weeks 3-4), in which by this period it rains frequently, whereas the average amount of rainfall in December is at $4.84 \mathrm{~mm}$. According to Rosliani et al. (2005) the planting time affects flowering and seed production. The dry season is the right time for flowering and onion seed production (Rosliani et al., 2005). Furthermore, as stated by Rosliani et al. (2016) which mentioned that the production of shallots seeds should produced during the dry season because at that time, besides the high activity of pollinating insects, there was also a low attack of pests and diseases. This could be potentially reducing seed yields. On this experiment, the main diseases were 
fusarium and caterpillar (Agrotis sp.). To anticipate the disease attack, prevention and control of disturbing organisms has been carried out regularly once a week with the application of fungicides and insecticides in accordance with the recommendations. The main pests that arise when plant growth are controlled by the Furadan application. To anticipate rain water exposure at the study site, plastic houses were used because of planting shallots to ensure that the treatment was not washed away by rainwater. Thus, plants can carry out vegetative growth until they succeed in entering the generative period and seed formation.

Instead of genetic and endoegnious factors of the palnt itself such varieties Rikanth and Schmid (2011) stated that flowering time can be influenced by various environmental factors. To increase yield, research needs to be done by under a higher altitude. This study was conducted at an altitude of $923 \mathrm{~m}$ above sea level while according to (Rosliani et al. 2016 ) that the production of optimal shallot seeds is cultivated at altitudes above $1,000 \mathrm{~m}$ above sea level. This is because flowering onions requires a low temperature of $7-12^{\circ} \mathrm{C}$ to induce flowering and $12-18^{\circ} \mathrm{C}$ to increase the size and time of flowering. The novelties of this study was the succefullnes on producing lower altitude of shallot (Biru Lancor varieties) seeds under various different treatments to dtecet the the different level of $\mathrm{N}$ fertilizer ans seaweed extract.

Observation to the weight of 100 seeds is very influential on overall seed yield. The higher the weight of 100 seeds, the higher the yield of seeds produced per unit area. However, there is no significantly effect from all treatments in this tudy. Lack of water during seed filling or seeding phase can reduce yields as a result of reduced seed size (Akil et al., 2007). Adding to this, total seed yields were calculated per $1000 \mathrm{~m}^{2}$ area. The results of the seeds in this study showed that the average seed yield on $\mathrm{N} 1$ was $748,835 \mathrm{~g}$ while the average yield on $\mathrm{N} 2$ was $867.46 \mathrm{~g}$ in which thos value are significantly different compare to control treatment. Average seed yields of seeds per $1000 \mathrm{~m}^{2}$ can reach $11.529 \mathrm{~g}$ (Rosliani et al., 2018), which meant higher than those value compare to the seed yield this study. The differences may due to the difference on shallot varieties and those geographical positions. The effect of the addition of seweed extract as biostimulant successfully increases the seed yield in the area in $1000 \mathrm{~m}^{2}$. The results of this study are in line with the research conducted by Du Jurdin (2015) on soybean plants which suggested that biostimulant had a significant effect on the number of crop pods, number of seeds per pod, number of branches, seed harvest. This is due to an increase in the absorption of N, P and K (Rathore, 2015)

The observation of tubers weight at 99 DAP showed that the lowest results were in the control (32 grams per plot size $2 \mathrm{~m}^{2}$ ) which was significantly different from all other treatments. The average tuber weight produced in the $\mathrm{N} 1$ treatment at all $\mathrm{RL}$ concentrations were at 58.00 grams while the N2 treatment in all concentrations produced a tuber average of 53.08. When compared with the control, tuber weight of $\mathrm{N} 1$ at all concentrations increased by $81.25 \%$ while in N2 treatment the increase was only $65.88 \%$. The results of this study are in line with the research conducted by Gebretsadik and Dechassa (2018) that the lower the nitrogen, the higher the formation of tubers were produced.

The lowest dry weight of shoots and roots were detected in the control, which is equal to $0.81 \mathrm{~g}$ an $0.09 \mathrm{~g}$ per plant which were significantly different from all other treatments particularly when it was compared to those of $\mathrm{N} 2$ treatment (high application of $\mathrm{N}$ fertilizer). When it was compared to controls, the treatment of $\mathrm{N} 1$ at all $\mathrm{RL}$ concentrations caused an average increasing of dry weight at $85.80 \%$ while treatment N2 at all concentrations resulted in an average increase in hihger dry weight at $87.65 \%$. This variable is closely related to plant height which has a pattern that is almost the same where the treatment of N2 doses produces a higher plant height compared to treatment $\mathrm{N} 1$. The dry weight of roots and leaves was measured at tuber harvesting 56 DAP. At the time of harvest, root and canopy formation is under maximum condition. Bertoni (1992) states that the dry weight of plant roots increases rapidly until the beginning of tuber formation and then slows down during the bulb enlargement phase.

Bertoni's (1992) study provides information that the dry weight of leaves and roots is known to be almost the same in all treatments of nitrate levels but the levels of nitrate in roots are known to increase significantly until near harvesting period. This result is along with 
the Jurdin et al. (2015) statement who also reported that at harvest time the absorption of nitrate in roots is known to be high. The addition of biostimulant applications to nitrogen nitrogen treatment increases the efficiency of absorption of nutrients including the mobilization and uptake of nutrients from the soil, transportation, storage and assimilation. The absorption of nutrients in these plants is also influenced by the density of plant roots. The results of this study indicate that crown and accrual dry weight were highest in the N2 $\mathrm{RL} 480$ treatment but were not different from the other treatments. In biostimulants, there are cytokinins, gibberellins and auxins. According to Aryanti (2012) that auxin increases the content of organic and inorganic substances in cells. These substances are converted into proteins, nucleic acids, Polysaccharides, and other molecular complexes. These compounds will form tissues and organs so that the wet weight and dry weight increase. Auxin can also increase plant osmosis pressure and softened cell walls which can increase water absorption and nutrients.

\section{REFERENCES}

1. Abdissa. Y., Tekalign. T. And Pant. K. M. 2011. Growth, bulb yield and quality of onion (Allium cepa L.) as influenced by nitrogen and phosporous fertilization on vertisol growth attributes, biomass production, and bulb yield. Afr. J. Agric. Res., 6(14): 3253-3258.

2. Achard. P, Cheng. $H$, de Grauwe. L.2006. Integration of plant responses to environmentally activated phytohormonal signals. Science (311): 91-94.

3. Anggria. L., A. Kasno., S. Rochayati. 2012. Effect of Organic Matter in Nitrogen Mineralization in Flooded and Dry Soil. J. Agr. and Biol. Sci., 7(8): 586-590.

4. Aryanti, W. S. 2012. Kinerja Zat Pemacu Pertumbuhan dari Cairan Rumput Laut Sargassum Polycistum dalam Meningkatkan Pertumbuhan Kedelai (Glycine Max L Merril). Anatomi Fisiologi. 17(2): 41-47.

5. Asli. S. And P.M. Neumann. 2010. Rhizosphere Humic Acid Interacts with Root Cell Walls to Reduce Hydraulic Conductivity and Plant Development. J. Plant and Soil, 336: 313-322.

6. Aqil, M., I.U. Firmansyah, and M. Akil. 2007. Pengelolaan airtanaman jagung.Balai Tanaman Serealia, Maros. http://balitsereal.litbang.deptan.go.id/

7. Balasubramanian S, Sureshkumar S, Lempe J, Weigel D. 2006. Potent induction of Arabidopsis thaliana flowering by elevated growth temperature. PLoS Genetics 2, e106.

8. Bashan. Y. and Holguin. G.1998. Proposal for Division of Plant Growth Promoting Rhizobacteria into Two Classifications: Biocontrol-PGPB (Plant Growth - Promoting Bacteria) and PGPB. J. Soil Biol. Biochem., 30(819): 1225-1228.

9. Bashan. Y., L.E.De-Bashan, S.R Prabhu, J.P. Hernandez. 2014. Advances in Plant Growth-Promoting Bacterial Inoculant Technology-Formulations and Practical Prspectives. J. Plant. Soil., 378: 1-33

10. Baswarsiati. 2005. Upaya BPTP Jatimdalam Penyediaan Benih Sumber, Aspek Teknisdan Pola Kemitraan Penyediaan Benih Sumber Bawang Merah. Makalah Pertemuan Apresiasi Penangkar Benih Bawang Merah di Brebes. Kementerian Pertanian. Jakarta.

11. Basuki R. S. 2009. Analisis Kelayakan Teknisdan Ekonomis Teknologi Budidaya Bawang Merahdengan Biji Botani dan Benih Umbi Tradisional. J. Hort., 19(2Bernier. G., J. M. Kinet, and R. M Sachs. 1981. The Physiology of Flowering. CRC Press Inc., Boca Raton. Florida. $148 \mathrm{p}$.

12. Bäurle I, Dean C. 2006. The timing of developmental transitions in plants. Cell; 125(4): 655-664.

13. Berg. G. 2009. Plant-Microbe Interactions Promoting Plant Growth and Health: Perspectives for Controlled Use of Microorganisms in Agriculture. J. Appl. Microbiol. Biotechnol., 84: 11-18.

14. Bertoni, G. F. Morard, C. Soubieille and J.M. Llorens. 1986. Growth and nitrogen nutrition of garlic (Allium sativum L.) during bulb development. Sci. Hort.J., 50(1992): 187-195. 
15. Biostimulant Coalition. 2018. What are Biostimulants? http://www.Biostimulant coalition.org/about/.1 September 2018.

16. Bocanegra. M.P., J.CLobartini, G.A. Orioli. 2006. Plant Uptake of Iron Chelated by Humic Acids of Different Molecular Weights. J.Commun Soil Sci. Plant. Anal., 37: 1-2.

17. Brewer. J.L. 2008. Onion and other Vegetable Allium. $2^{\text {nd }}$ Edition CAB International, Wallingford. UK. 36p.

18. Buwalda, J.G., 1986. Nitrogen nutrition of garlic (Allium sativum L. ) under irrigation. Crop growth and development. Sci. Hort. J., 29(1-2): 55-68.

19. Csizinszky, A.A., 1986. Response of tomatoes to foliar biostimulant sprays. Proceedings of the Florida State Horticultural Society, 99: 353-358.

20. Calvo P., L. Nelson, J.W.Kloepper. 2014. Agricultural Uses of Plant Biostimulants. J. Plant Soil, 383: 3-41.

21. Chen T.H.H. and N.Murata. 2011. Glycinebetaine Protects Plants Against Abiotic Stress: Mechanisms and Biotechnological Applications. J. Plant. Cell Environ., 34: 1-20.

22. Chouliaras. V., M. Tasioula, C. Chatzissavvidis, I. Therios, E. Tsabolatidou. 2009. The Effects of a seaweed extract in Addition to Nitrogen and Boron Fertilization on Productivity, Fruit Maturation, Leaf Nutritional Status and Oil Quality of The Olive (Olea europea L..) Cultivar Koroneiki. Journal of the Science of Food and Agriculture, 89: 984988.

23. Craigie. J.S. 2011. Seaweed Extract Stimuli in Plant Science and Agriculture. J. Appl. Physiol., 23: 371-393.

24. DirektoratJendralHortikultura. 2010. Statistik Produksi Hortikultura Tahun 2009 (AngkaTetap). Kementerian Pertanian. Jakarta.

25. Dodd. I.C. and J.M. Ruiz-Lozano. 2012. Microbial Enhancement of Crop Resource Use Efficiency. J. Biotechnol, 23: 236-242.

26. Du Jurdin, P. 2015. Plant biostimulants: Definision, concept, main categories nand regulation. Sci. Hort.J., 196: 3-14.

27. Eldardiry. I, M, Entisam, A. El-Hady, M.S.A. Aboelli, Aboe-El-Kheirand. 2015. Effect of Organic Manure Sources and NPK Fertilizer on Yield and Water Productivity of Onion (Allium cepa L). Global Advanced Research J. Agr. Sci., 4(11): 803-808.

28. Esteves da J.C.G Silva, A.A.S.C.Machado, C.J.S Oliveira.1998. Effect of $\mathrm{pH}$ on Complexation Fe(III) with Fulvic Acids. Environ Toxicol Chem, 17: 1268-1273.

29. European Biostimulants Industry Council. 2012. What are Biostimulants? http://www.biostimulants.eu/about/what-arebiostimulants/. 17 Januari 2017.

30. Fan. J., H.Mingde, S.S. Malhi. 2010. Accumulation of Nitrate-N in the Soil Profle and its Implications for the Environment under Dryland Agriculture in Northern China: A Review. Canadian J. of Soil Sci. p. 429-440.

31. Fritsch. R.M. and N.Friesen. 2002. Evolution, Domestication and Taxonomy. In: Rabinowitch D., Currah L. (Eds), Allium. J.Crop Sci.: Recent Advances. Wallingford, Cab International, p. 5-30.

32. Gebretsadik. K and N. Dechassa. 2018. Response of onion (Allium cepa L.) to Nitrogen fertilizer rataes and spacing under rain fed condition at Tahtay Koraro. Scientific Reports, (2018) 8: 9495, Tanggal akses 19 April 2019.

33. Ghoname, A.A, Mona. G, G.S. Riad and W.A. El Tohamy. 2009. Effect of Nitrogen Form and Biostimulants Foliar Application on Growth, Yield, and Chemical Composition of Hot pepper Grown under sandy soil conditions. Res. J. Agric. And Biol. Sci., 5(5): 840-852.

34. Ghosh P., A.K. Kashyap. 2003. Effect of Rice Cultivars on Rate of N-Mineralizaton, Nitrification and Nitrifier Population Size in an Irrigated Rice Ecosystem. J. Applied Soil Ecology, 24: 27-41.

35. González. A, J.Castro, J.Vera, A.Moenne. 2013. Seaweed Oligosaccharides stimulate Plant Growth by Enhancing Carbon and Nitrogen Assimilation, Basal Metabolism, and Cell Division. J. Plant Growth Regul, 32: 443-448.

36. Gustfson, A. A. Hand book of fertilizers, their source makes up, efect and use 3rd ed. India pp78-88 (Agrobios, 2010). 
37. Hayat. R., S..Ali, U.Amara, R.Khalid, I.Ahmed. 2010. Soil Beneficial Bacteria and Their Role in Plant Growth Promotion: a Review. Ann Microbiol, 60: 579-598.

38. Hilman. Y, R. Rosliani,R. P.Endah. 2014. Pengaruh Ketinggian Tempatterhadap Pembungaan, Produksi, dan Mutu Benih Botani Bawang Merah. J. Hort., 24(2).

39. Hilman. Y, G. A. Sopha, and L. Lukman. 2014. Nitrogen effect on production, nutrients Uptakes and Nitrogen Use Effeciency of shallot (Aliium cepa var aggregatum). ABB Bioflux; (2): 128-133.

40. Jung. C, Müller AE. 2009. Flowering time control and applications in plant breeding. J. Trends in plant. Sci., 14(10): 563-573.

41. Kato. T., M. Yamagata, S. Tsukaraha. 1987. Nitrogen: Nutrition its Diagnostic and Post Harvest Bulb Rot in Onion Plant. Bull.Shikoku.Nat.Agric.Exp.Station, 48: 26-49.

42. Kementerian Pertanian. 2014. Budidaya Bawang Merah di BPTP Bangka. BPTP Bangka. Badan Litbang Pertanian. Kementerian Pertanian. Jakarta.

43. Khan. W, U.P.Rayirath, S.Subramanian. 2009. Seaweed Extracts as Biostimulants of Plant Growth and Development.J Plant. Growth Regul, 28: 386-399.

44. Kim. D-H, Doyle. M. R, Sung. S, Amasino R. M. 2009. Vernalization: winter and the timing of flowering in plants. Annual Review of Cell and Developmental25: 277-299.

45. Kloepper. J.W., R.Lifshitz, R.M.Zablotowicz. 1989. Free Living Bacterial Inocula for Enhancing Crop Productivity. Trends Biotechnol, 7: 39-44.

46. Krontal. Y, R. Kamenetsky, H. D. Rabinowitch. 2000. Flowering physiology and some vegetative traits of short-day shallot: A comparison with bulb onionJournal of Horticultural Science \& Biotechnology, 75(1): 35-41.

47. Lee. J, Lee. I. 2010. Regilation and function of SOC1, a flowering pathway integrator. J. of exp. botany 61(9): 2247-2254.

48. Lobartini, J.C, K.H.Tan, C. Pape. 1998. Dissolution of Aluminum and Iron Phosphate by Humic Acids. Commun Soil Sci Plant Anal, 29: 535-544.

49. Mancuso, S., Azzarello, E., Mugnai, S., Briand, X. 2006. Marine Bioactive Substances (IPA Extract) Improve Foliar Ion Uptake and Water Stress Tolerance in Potted Vitis Vinifera Plants. J. Adv Hort. Sci, 20: 156-161.

50. Marschner, H. 1995. Mineral Nutrition of higher Plants. 2nd. edition, Academic Press, San Diego, London.

51. Martínez. C, Pons. E, Prats. G, León. J. 2004. Salicylic acid regulates flowering time and links defence responses and reproductive development.The Plant J., 37: 209-217.

52. Michaels. S. D, Amasino R. M. 2000. Memories of winter: vernalization and the competence to flower. J. Plant Cell and Env., 23(11): 1145-1153

53. Mikha M.M., C.W.Rice, J.G.Benjamin. 2006. Estimating Soil Mineralizable Nitrogen Under Different Management Practices. J. Soil Sci. and Society of America, 70: 15221531.

54. Milton. R.F. 1964. Liquid Seaweed as a Fertilizer. Proc Int Seaweed Symp, 4: 428-431.

55. Mouradov A, Cremer F, Coupland G. 2002. Control of flowering time interacting pathways as a basis for diversity. The Plant Cell Online 14 (suppl 1): S111-S130.

56. Ngullie. E., V.B Singh, A.K.Singh, H.Singh. 2011. Fertilizing for Sustainable Onion Production System. Better Crop, 95(1).

57. Nasreen. S., Haque. M. M., Hossain, M. A. and Farid, A. T. M. Nutrient uptake and yield of onion as infuenced by nitrogen and sulphur fertilization. Bangladesh J. Agric. Res., 32(3), 413-420.

58. Norrie. J. and J.P Keathley. 2006. Benefits of Ascophyllum nodosum Marine-Plant Extract Applications toThompson Seedless Grape Production. Acta Hortic, 727: 243-247.

59. Putterill. J, Laurie. R, Macknight. R. 2004. It's time to flower: the genetic control of flowering time. Bioessays 26(4): 363-373.

60. Putrasamedja S. 1995. Pengaruh Jarak Tanampada Bawang Merah (Allium cepa Var. Ascalonicum Baches) dari Bijit terhadap Produksi. J. Hort, 5(1). 
61. Rosliani, R, Suwandi \& Sumarni, N 2005, 'Pengaruh waktu tanam and zat pengatur tumbuh mepiquat klorida terhadap pembungaan and pembijian bawang merah (TSS)', J. Hort., vol. 15, no. 3, pp. 192-198.

62. Rosliani. R, E. R.Palupi, danY.Hilman. 2013. Pengaruh Benzil Amino Purindan Boron terhadap Pembungaan, Viabilitas Serbuk Sari, Produksidan Mutu Benih Bawang Merah di DataranRendah. J. Hort, 23(4).

63. Rosliani. R. 2014. Teknik Aplikasi Benzil Amino Purin dan Pemeliharaan Jumlah Umbelper Tanamanuntuk Meningkatkan Produksidan Mutu Benih Botani Bawang Merah (True Shallot Seed) di DataranTinggi. J. Hort, 24(4).

64. Rosliani. R, Y. Hilman, N. Waluyo, M. P. Yufdy. 2016. Dissemination of Technology for Shallot (Allium Ascalonicum L.) Seed Production Using True Shallot Seed (TSS) in Indonesia. ActaHorticulturae1143: VII International Symposium on Edible Alliaceae.

65. Rosliani. R. 2016. Pengaruh $\mathrm{GA}_{3}$ terhadap Viabilitas dan Vigor Benih Bawang Merah. Prosiding Seminar Nasional Pengembangan Teknologi Pertanian Politeknik Negeri Lampung.

66. Rosliani. R, Y. Hilman, I. Sulastrini, M. P. Yufdy. 2018. Evaluasi paket teknologi produksi benih TSS Bawang Merah varietas Bima Brebes di dataran tinggi. J. Hort. Vol. 28 No. 1, Juni 2018: 67-76

67. Schiavon. M., D. Pizzeghello, A.Muscolo, S. Vaccoro,O.Francioso, Nardi. 2010. High Molecular Size Humic Substances Enhance Phylpropanoid Metabolism in Maize (Zea mays L.).J. Chem. Ecol., 36: 662-669.

68. Searle I, Coupland G. 2004. Induction of flowering by seasonal changes in photoperiod. The EMBO J., 23(6): 1217-1222.

69. Setjen Pertanian. 2017. Outlok TPHORTI. Kementerian Pertanian Republik Indonesia. http:Ilepublikasi.setjen.pertanian.go.id. 18 September 2018.

70. Simpson. A.J., W.L.Kingery, M.H.B.Hayes. 2002. Molecular Structures and Associations of Humic Substances in the Terrestrial Enviornment.

71. Sivasankari S., Venkatesalu V, Anantharaj, M. Chandrasekaran M. 2006. Effect of seaweed extract on the growth and biochemical constituents of Vigna Sinensis L. Bioresiurce Technology, 97 1745-1751

72. Srikanth. A, Schmid. M. 2011. Regulation of flowering time: all roads lead to Rome. J. Cell. and Mol. Life Sci.,68, 2013-2037Naturwissenschaften, 89: 84- 88.

73. Stevenson. F.J. 1994. Humus Chemistry: Genesis, Composition, Reactions. Wiley, New York.

74. Stirk, W.A., van Staden, J. 1997. Comparison of Cytokinin and Auxin like Activity in Some Commercially Used Seaweed Extracts.J Appl Phycol.

75. Sulistiono. R. 2010.

76. Sumarni. N and Rosliani. R. 2010. Pengaruh Naungan Plastik Transparan, Kerapatan Tanaman, and Dosis $\mathrm{N}$ terhadap Produksi Umbi Bibit Asal Biji Bawang Merah. J. Hort., 20(1).

77. Sumarni. N, R.Rosliani, R. S.Basuki. 2012. ResponsPertumbuhan, HasilUmbi, danSerapan Hara NPK Tanaman Bawang Merah Terhadap Berbagai Dosis Pemupukan NPK pada Tanah Alluvial. Jurnal Hortikultura, 22(4).

78. Sumiati. E. and Gunawan. O. S. 2007. Application of mychorizha biofertilizer to increase NPK uptake and influence on yield and quality of shallot. J. of Hort; 17(1): 34-42.

79. Sung. S. B, Amasino R. M. 2004. Vernalization in arabidopsis thaliana is mediated by the PHD finger protein VIN3. Nature; 427(6970): 159-164.

80. Sytar. O., A.Kumar, D.Latowski. 2013. Heavy Metal-Induced Oxidative Damage, Defense Reactions, And Detoxification Mechanisms In Plants. J. Acta Physiol Plant, 35: 985-999.

81. Taiz L, Zaiger E. 2006. Plant physiology (4th ed.). Sinauer Associates, Inc.: Massachusetts.

82. Tarakhovskaya. E. R, Y. I.Maslov, M. F.Shishova. 2007. Phytohormones in Algae. Russ. Plant Physiol J, 54: 163-170. 
83. Varanini. Z and R. Pinton. 2001. Direct Versus Indirect Effects of Soil Humic Substances on Plant Growth And Nutrition. In: Pinton R, Varanini Z, Nannipieri P (eds) The rhizosphere. Marcel Dekker, Basel.p.141-158.

84. Vessey. J.K. 2003. Plant Growth Promoting Rhizobacteria as Biofertilizers.J Plant Soil, 255: 571-586.

85. Yohannes. K.W., D.Blew, A.Debela. 2013. Effect of Farmyard Manure and Nitrogen Fertilizer Rate and Yield Component of Onion (Allium cepa) at Jimma, Southwest Ethiopia.Asian J. Plant Sci. DOI: 10.3923/ajps.

86. Yusuf R., Syakur A, Budiatno. 2016. Aplication of some types of seaweed on the growth and yields of shallot (Allium ascalonicum L.). Agroland: the Agricultural Sciences Journal $3(2)$.

87. Zhang J., J. Qqin., W. Yao., L. Bi., T. Lai., X. Yu. 2009. Effect Oflong-Term Application of Manure and Mineral Fertilizers on Nitrogen Mineralization and Microbial Biomass Paddy Soil During Rice Growth Stages. J. Plant Soil Environ., 55(3): 101-109.

88. Zimmerli. L., B. H.Hou, C. H.Tsai. 2008. The Xenobiotic Beta Aminobutyric Acid Anhances Arabidopsis Thermotolerance. J. Plant, 53: 144-156. 